\title{
Note from the Editor Regarding this Special Issue
}

\author{
Daniel G. Bates
}

Published online: 8 February 2011

(C) Springer Science+Business Media, LLC 2011

Studies of the Subak: New Directions, New Challenges a collection of papers edited by Nitish Jha and John W. Schoenfelder is a welcome addition to Human Ecology's list of special issues focusing on important topics in research and theory. Often collections such as this have an impact greater than merely the sum of the individual articles. Nitish Jha, John W. Schoenfelder and their colleagues have made outstanding contributions here across a number of disciplines all sharing a focus on the water management systems of one island, Bali, the study of which has energized and informed research on water management and distribution on several continents.

Since the practical constraints attending a bimonthly peer reviewed journal require that we make full use of our page budget, we have included two additional articles not selected by our guest editors. Both seem singularly appropriate here as they deal with water, its scarcity, and the myriad issues attending its use and distribution.

Zongze $\mathrm{Hu}$ uses an unusual but effective perspective to document and understand villagers' efforts to secure a reliable supply of drinking water in a rural community in North China. He views this through the changing fortunes of the Ninth Dragon, a water god whose rise, fall, and ultimate reinstatement as an important deity reflects village politics and disputes over water, as well the efforts of the central government to secure local control and authority. In this fine grained account, the ponds, the canals, the ditches, the wells, the water towers, the water pipes, and the water switching station are all indicators of the political power and mobilizing abilities of different generations of village leaders. The resurgence of the Dragon's worship since the early 1980s partly resulted from the state's more relaxed ideological control, but it has facilitated the emergence of a new group of religious leaders who compete with secular leaders for influence and authority.

Ayron Strauch and Astler Almedon, in a paper using both qualitative and quantative data, examine traditional resource management among the Sonjo in rural Northern Tanzania, with particular reference to catchment forest protection and water quality, which is often overlooked in studies of water management. They document the ecologically relevant TRM and describe the differences between traditionally managed water sources and formal government managed resources. Their insightful examination of traditional methods of water conservation and users perceptions of water quality provides insight into how communities in resource-stressed regions thrive despite seasonal droughts and flooding.

D. G. Bates $(\square)$

Department of Anthropology, Hunter College, C.U.N.Y.,

695 Park Avenue,

New York, NY 10065, USA

e-mail: humaneco@hunter.cuny.edu 